\title{
Critical Challenges Of The South African School System
}

Nelda Mouton, Ph.D., North-West University, South Africa G.P. Louw, Ph.D., North-West University, South Africa G. Strydom, Ph.D., North-West University, South Africa

\begin{abstract}
The emphasis in the new curriculum after 1996 in South Africa was placed on the transition from the traditional aims and objectives approach to Outcomes-based education (OBE) and Curriculum 2005. This paradigm shift was interpreted as a prerequisite for achievement of the vision of an internationally competitive country. When analysing the school system in South Africa it became clear that the education system was flawed, with poorly performing teachers, poor work ethics, lack of community and parental support, poor control by education authorities, poor support for teachers and very low levels of accountability. These factors further spilled over into the morale of learners and could be seen in the lack of discipline, brutal violence in schools, low moral values, truancy, absenteeism, late coming and high dropout rates from Grade 1 to Grade 12 and very poor performance in essential areas such as Mathematics and Literacy. Citizens in historically disadvantaged areas tend to become victims of poverty, gangs and drug abuse. These factors further blend with the evil of politics in South African schools which are furthermore plagued by various forms of corruption and socio-economic challenges. Eighteen years after the end of the apartheid dispensation, apartheid is still blamed by many for any real or imagined ills in society, but the reality is that there is no political will to enforce the law or to meet public expectations of accountability, efficiency and delivery. In the light hereof, recommendations are proposed that will address these challenges. The critical message of this article will convey that the fact of the matter is that learner enrolment is not the same as attendance and attendance does not imply learning. Therefore, teaching in South Africa must become a profession of preference and pride as opposed to the present very lackadaisical attitude.
\end{abstract}

Keywords: Outcomes-Based Education; Discipline; Corruption; Politics; Apartheid; South Africa

\section{INTRODUCTION}

C n 1995 the Minister of Education announced the introduction of a new curriculum, with outcomes-based education (OBE) as the foundation (DoE, 1997). The curriculum was launched in March 1997 and became known as Curriculum 2005 - and from the outset it evoked mixed reactions from various quarters. This curriculum was a political initiative (Harley \& Wedekind, 2004; Fiske \& Ladd, 2004) and an attempt by government to restructure the unequal education system in an attempt to equalise educational opportunities among the various population groups (DoE, 1997). Advocates of OBE hailed the new curriculum as a means of meeting the needs of all learners regardless of their environment, ethnicity, economic status or disability, and claimed that the implementation of OBE would result in greater curriculum focus, better instructional methods and reliable and valid assessment practices (Lombard, 2010). OBE is eclectic when considering its philosophical foundations as it is based on a blend of behaviourism, pragmatism, reconstructivism and the critical theory (Lombard, 2010).

This curriculum was revised in 2004 and renamed the Revised National Curriculum Statement (RNCS) for the General Education and Training Band (Zewotir \& North, 2011) and in 2006 as the National Curriculum Statements for the Further Education and Training Band (Lombard, 2010). Potgieter and Davidowitz (2010) state that at the end of 2008 the first cohort of students who had been taught according to the new curricula from Grades 
1-12 wrote the new National Senior Certificate (NSC) examinations. The results of this examination received careful scrutiny by bodies such as Umalusi in an attempt to determine whether there had been a shift in standards as measured against previous years prior to Curriculum 2005 (C2005). When this particular cohort of learners entered tertiary studies, it became apparent from the results of the first class tests that they were not adequately prepared for tertiary studies (Nel \& Kistner, 2009). Potgieter and Davidowitz (2010) state that preparedness for tertiary education does not consist only of content knowledge, but also of conceptual understanding of fundamental concepts assumed as pre-knowledge for tertiary education and it seemed that students lacked these abilities.

The concerns about the declining quality of education include the issue of under-prepared learners resulting from internal promotion practices and the need by schools to achieve high pass rates in especially Grade 12. As a result, educators at secondary level blame the educators at the preceding levels for producing learners who cannot read or write at the levels needed for tertiary study, among others, thus making their work difficult (Matoti, 2010).

The South African education system remains in a state of transformation as the government is in a process of grappling with legacies of the past, whilst balancing risks and opportunities for the future (Zewotir \& North, 2011). It is essential that especially African countries must develop education systems that allow as many children as possible to go to school and to seek an education of a high-enough quality to enable them to enter the labour market and contribute to the economy in a manner guaranteed to attract investors (Herbst \& Mills, 2012). Grant, Jasson and Lawrence (2010) indicate that it is the majority of South African schools that have inherited the legacy of dysfunction. The question rightfully asked by the same researchers is: Why do some schools manage to survive, if not thrive, in adverse contexts where neighbouring schools remain in crisis? (Grant, et al, 2010). In this regard Christie and Potterson (1997) found that risk factors include poverty, unemployment, political violence, faction fighting, gang warfare and social problems. These factors inevitably result in traumatised learners and learners with learning difficulties.

When taking these notions into account it is deemed essential to attest to the challenges the education system is facing at present and to make constructive recommendations for the amelioration of the present highly untenable situation.

\section{AIMS OF THE STUDY}

Jansen (1999) predicted that teachers would get lost among the complex and inaccessible structures and issues of OBE and that they would fall back on outdated traditional teaching practices. Furthermore, inadequately trained teachers, inadequate support and the absence of teaching and learning resources would directly contribute towards the failure of the curriculum. In the light hereof, this article will focus on the challenges facing education in South Africa in 2012 and recommendations about the abatement of these challenges will be proposed.

\section{METHOD AND PROCEDURE}

The aims of this article will be achieved by means of a literature review and the findings will be presented in narrative format. Various policies and views of critics will be discussed in order to identify the challenges and to propose recommendations for education. The databases used were EBSCO, Sabinet online, books, journals and newspapers. They keywords include: Outcomes-based education, assessment, discipline, results, underperformance, governance, violence, values, poverty, performance, accountability, absenteeism, truancy, corruption, politics, apartheid.

\section{CHALLENGES FACING THE SCHOOL SYSTEM IN SOUTH AFRICA}

In order to comprehend the vastness of the challenges encountered in the school system, it is deemed necessary to conceptualise some of the major challenges as follows:

- Challenges facing learners. These include violence in schools, low moral values, high dropout rates, late coming, absenteeism and truancy. 
- $\quad$ Challenges facing teachers. These include aspects such as poor results, under-performance by educators and lack of effective school governance.

- Indirect challenges: These include lack of community support, politics in South African schools, corruption and socio-economic challenges.

\subsection{Challenges facing learners}

\subsubsection{Violence in schools}

The school plays a vital role in a learner's learning and socialization and it is therefore essential that schools offer a safe environment in which authentic learning and development can take place (Ngqela \& Lewis, 2012). Growing up in an environment of fear and danger is creating a generation of young people whose lives are shaped by threat (Benjamin, 2011a). Violence in schools is not entirely unique to South Africa as children worldwide are raised within the context of a catastrophic breakdown of traditional family systems, unemployment, high levels of substance abuse and widespread violence (Schoeman, 2010). Unfortunately, violence is an everyday fact in many South African schools as evidenced when one reads daily newspapers in South Africa. As just one example, it was reported that learners in Qwa-Qwa did not go to school for several days in June 2011 due to ongoing violence in the community (Tau, 2011) - and this has become a sad pattern in the South African schools context. The reason for the violence in that community was that the community was displeased with the newlyelected mayor .It is not uncommon for schools to suffer disruption when dissatisfaction with other social conditions boils over in communities. Sifile (2011) reports about the fact that a seven-year old boy was undergoing antiretroviral treatment after he was allegedly raped at school during school hours in May 2011. In Delft (a small town in South Africa) parents started waiting outside a local high school to walk their children home each day, saying that they were terrified that their children would get caught in the crossfire of vicious gang fights as a 15-year old, a learner at this school, had been stabbed to death during a fight with fellow learners (Bezuidenhout, 2011). Also, children often dodge bullets on their way to school at Lavender Hill School. At this school learners were told on arrival before their Grade 12 examination commenced that day that one of their classmates had been shot and hospitalized (Fredericks, 2011a). These incidents raise serious concerns about the safety of learners in South African schools - and in a number of areas in the country the violence has become endemic with no real prospect of improvement.

\subsubsection{High dropout rates}

In South Africa, two out of ten learners drop out of school after Grade 3, four out of ten after Grade 9, six out of ten after Grade 10 and 7.3 after Grade 11. This means that less than a quarter of learners who begin Grade 1 complete Grade 12 (Badat in Pather, 2011). It is interesting to note that of the 7000 secondary schools in the country, $10 \%$ (independent and Model $\mathrm{C}$ schools included) produce $60 \%$ of all students who can attend university. Another $10 \%$ from historically disadvantaged schools produce a further $20 \%$ of such students whereas the rest of the schools produce the other 20\% qualifying for university entrance (Badat in Pather, 2011). The research of Rademeyer (2012) reflects that of the total of 11063399 learners enrolled in 2011 in South African schools, 1,2 million $(11,1 \%)$ had to repeat their grades in 2012. This number of repeaters is more than the total number of learners in Mpumalanga (963 193) and the Western Cape (920 097). Furthermore, in 2010, 146000 Grade 9's had to repeat the school year, while in 2011, 155394 learners had to repeat their current year. Such statistics indicate that it is difficult for a learner to repeat Grades 2 to 7 , but the reversal of dropout is evident when learners reach Grades $10-12$. The repeat rate then increases from an overall $11,1 \%$ to $24,7 \%$ and $22,9 \%$ respectively for Grades 11 and 12 (Rademeyer, 2012; Kruger, 2012). It also happens that some of these learners need to repeat Grade 11 or 12 for a third or a fourth time (Rademeyer, 2012), and the concomitant of this is that there is a disproportionate number of learners in these grades who are over-age in terms of the class average. In this regard Gernetzky (2011a) states that in some cases $80 \%$ of graduates came from $10-20 \%$ of schools and $40 \%$ schools produced no university graduates whatsoever.

Fredericks (2011b) indicates that a report by the Department of Basic Education shows that in the age group 16-18 years, the proportion of coloured children who attend school is smaller than those of other population groups. It was found that financial pressures, teenage pregnancy and substance abuse combined with other factors at 
school, and these factors, including a serious lack of stimulation and support, have led to young people disengaging from their education and eventually dropping out of school (Jones, 2011a). Pregnancies are also a serious concern adding to the high drop-out rate. In January 2011 a team of primary health-care workers was sent to a high school in the Limpopo Province where 57 teenage girls had fallen pregnant before starting the new school year and media reports indicate that learners as young as 13 were pregnant (Citizen Reporter, 2011; Lansdowne, 2011). This is despite the fact that learners receive education in Life Orientation on sexual behaviour, HIV/AIDS and related issues.

According to an international comparative study, South Africa's average level of repetition in primary schools of 7\% was higher than the 5\% for developing countries. For developed countries it was less that 1\% (Jones, 2011a).

Jones (2011b) indicates that the department has put in place a number of initiatives and incentives for learners to attend schools. These include the nutrition programme, no-fee schools, the provision of workbooks and textbooks, the expansion of Grade R (pre-school year) and the reduction of teachers' administrative loads.

\subsubsection{Late coming, absenteeism and truancy}

It is not unusual to see learners in many parts of the country being late, dawdling outside the school grounds, and leaving school very early. It seems that proper supervision is lacking and this is ironically more obvious during times of examination where learners "study" at home and only attend school for the duration of the examination session (Fredericks, 2011c). The Western Cape Province declared that they wanted their learners to be in school during the June 2011 examination (Fredericks, 2011c). It is also noted by Fredericks (2011c) that Grade 12 learners are entitled to five days of study leave before the start of the National Senior Certificate examinations in October, but not before the June examinations. Teachers were also expected to be at school for the full school day, irrespective of whether they had invigilation duties. To support these statements, it was reported by Creeze (the MEC of Education in Gauteng) that she drove past an informal settlement to see 120 children late for school (Staff Reporter, 2011). To highlight the sad state of affairs regarding the schooling system in South Africa, it needs to be mentioned that Gauteng is one of the provinces doing best, comparatively speaking, when it comes to the upgrading of teachers and improving on Grade 12 results.

\subsection{Challenges facing teachers}

\subsubsection{Implementation of OBE and C2005}

Education in South Africa is controversial and associated with change. In this sense educational reform is an attribute to change (Lombard, 2010). This reform process culminated in 1997 when Curriculum 2005 was launched and had substantially changed South African education (Lombard, 2010). Apart from complex structures as introduced by OBE and C2005, assessment is even more problematic (Jansen, 1999) and outrage against it remains intense (Warnich \& Wolhuter, 2010).

Teachers from the start experienced OBE as a product of a bureaucratically driven curriculum process where the "top-down" management style took teachers aback and left them unsure (Rogan, 2000). Waghid (2001) questions the education principle of critical thought on which OBE and C2005 was based. The fundamental changes for assessment proposed by OBE also contributed substantially to teachers' negative reactions and resistance as they found it difficult to maintain a balance between teaching and assessment time (Warnich \& Wolhuter, 2010). Teachers also felt negative towards OBE and felt that a lack of sustained professional development was a serious shortcoming (Matshidisa, 2007; Reyneke, 2008; Warnich, 2008).

Furthermore, the most recent round of South African curriculum review known as CAPS (Curriculum and Assessment Policy Statement) is being implemented in Grades 1, 2, 3 and 10 in 2012. In 2013 it will be implemented in Grades 4, 5, 6, and 11. Plans to train teachers to cope with this deviation from OBE still have to be finalised in the KwaZulu Natal and North-West Provinces. Thus, implementation of CAPS, in a sad repetition of OBE, has taken place without sufficient training of teachers (Nkosi, 2012). 
Meyer and Warnich (2010) state that recurring challenges are the following:

- Inadequate outcomes-based assessment training of teachers;

- $\quad$ inadequate departmental support and guidance;

- $\quad$ lack of physical resources, teaching and learning support materials;

- $\quad$ overcrowded classrooms; and

- $\quad$ the administrative overload that teachers experience.

\subsubsection{Poor results in literacy and numeracy}

South African students score poorly in literacy and numeracy tests when compared with students from other African countries and when considered what should be expected almost 20 years after the achievement of democracy (HSRC, 2012). The TIMSS (Trends in Mathematics and Science Study), PIRLS (Progress in International Reading and Literacy Study), and SACMEQ (Southern and Eastern Africa Consortium for Monitory Educational Quality) show that South African learners perform well below their academic potential (HSRC, 2012; Howie, 2004). Gernetzky (2011b) reports that the literacy and numeracy rates of South Africa's learners are among the lowest of their peers, despite the large sums of money spent on education each year.

In 2006, Grade 6 learners achieved an average of 28\% in languages and 30\% in Mathematics. Basic Education Minister, Angie Motshekga, said that these results would serve as benchmarks. Further independent benchmark tests for Grade 6 learners were also conducted in 2007 and 2009 in the Western Cape. The outcomes were poor and only $17.4 \%$ of learners were competent in numeracy (Potgieter, 2010). The outcome of these tests indicates that one should be ashamed of an average of 35\% in literacy and $28 \%$ in numeracy for Grade 3s, and $28 \%$ in literacy and 30\% in numeracy for Grade 6 which means that the majority of South African children cannot read or count at an appropriate level (Editorial Comment, 2011). These statistics once again prove that South Africa's school system is inefficient and faces a major performance quality challenge (Govender, 2012a).

\subsubsection{Under-performance of educators}

The country's universities are investigating why African school leavers do not want to teach children aged between five and nine and in this regard Govender (2011) states that African trainee teachers were opting to teach high school learners, instead of their younger counterparts. A snap survey at four universities indicated that only 15 out of 324 teachers who graduated with a teaching degree specializing in the Foundation Phase were African (Govender, 2011). The outcomes of the TIMSS tests also indicated that teachers whose learners were more likely to achieve lower results were those with strong mathematical pedagogical beliefs (Howie, 2004). Teachers' underperformance could be a result of constant curriculum change and additional training sessions intended to "teach the new curriculum" (Bertram, 2011).

In the Eastern Cape Province in 2010, the results in different grades were poor. Only half of the Grade ones passed and only half of Grade 7s made it to secondary school (Editorial comment, 2011). South Africa's school system is extremely inefficient as the country can claim nearly $100 \%$ enrolment in Grade 1 with fewer than a quarter of these learners being expected to write Grade 12 (Motala in Gernetzky, 2011a) - a level of wastage that the country can ill afford in any context, not least being providing appropriately trained workers for the economy.

Another factor that affects the quality of teaching is the morale of the teachers in the schooling system of South Africa as this will have an impact on the standard of education. A quantitative analysis of a research conducted by Matoti (2010) indicates that the majority of educators are uncertain about their own futures in education as well as the future of education per se in South Africa. Some of their fears and concerns include the political and economic climate in the country, changes in policies, and changes in the curriculum, high rates of teacher attrition, unsafe school environments, unsatisfactory working conditions, the declining quality of education, role conflict, poor teacher morale, unprofessional conduct of educators, lack of co-ordinated C2005 workshops, poor management and leadership in schools, as well as a lack of accountability (Matoti, 2010). It is also acknowledged that principals play a critical role in focusing decisions and instilling a culture of learning at schools (Editorial 
comment, 2011). These are all serious potholes that the education system in South Africa is facing - and it affects the entire system, commencing from pre-school and continuing up to university level.

It is therefore important that intense efforts of the dismal situation in education should be rectified where possible.

\subsubsection{Lack of proper school governance}

One of the hallmarks of a democratic education system is its character of inclusivity, transparency and accommodativeness of all relevant stakeholders, and more specifically, the governing bodies of schools (Naong \& Morolong, 2011). The South African Schools Act, Act 84 of 1996 (DoE, 1996) provides for the establishment of school governing bodies with considerable powers at all public schools. These would include the school principal, elected representatives of parents, teachers and non-teaching staff. The Act (DoE, 1996) further stipulates functions allocated to SGBs that include the maintenance and improvement of school property, determining the extra-mural curriculum of the schools, the choice of subject options in terms of provincial curriculum policy, the purchasing of textbooks, educational materials, payment for services to the school or other functions consistent with Act 84 of 1996 (DoE, 1996) and any applicable provincial law.

School governance is still experiencing insurmountable challenges as School Governing Bodies (SGBs) in areas where they had not existed traditionally are not trained before they start their work and this manifests in some challenges such as unfamiliarity with meeting procedures, difficulties in managing large volumes of administrative work and not knowing appropriate legislation (Xaba, 2011). A serious concern is the lack of needed knowledge and skills for financial management and the lack of collaboration between the principal and the members of the SGBs (Mestry, 2004). Steyn, Steyn and De Waal (2011) identify unemployment which gives rise to the parents' low socio-economic status, as a reason for poor parental involvement at schools. On the other hand, educators blame the low level of education of SGB members as a reason for low performance. This means that members of the SGBs are unable to execute their roles and responsibilities with disastrous consequences for the schools where they have to provide governance and oversight. They are also easily manipulated (thus subject to corruption and participation in nepotistic practices), unable to participate in decision making and are continually absent from meetings and workshops. This tendency is inevitably more visible in historically disadvantaged schools (Xaba, 2011).

\subsection{INDIRECT CHALLENGES}

\subsubsection{Lack of community support}

Naong and Morolong (2011) state that education in historically disadvantaged schools has been subject to problems that undermine parental involvement. In many cases the community is failing to take ownership of schools (Halata, 2011). It should be noted that not only is community support needed to improve this situation but classroom teaching and performance are as important in the effort to bring back discipline and safety at schools.

One can state that the community has an influence on what is happening at school and that the school is a mirror image of the community within which it is situated. Learners reflect these experiences and it is crucial that the focus should be on positive relationships and that issues of better security measures should be addressed as well as parental roles and community involvement (Ngqela \& Lewis, 2012).

\subsubsection{Politics in schools}

Jansen (1999) predicted that OBE would fail not because politicians and bureaucrats are misinformed about conditions in South African schooling, but because the education policy was being driven by political imperatives that had little to do with the realities of classroom life. Education MEC, Minister Mchunu from KwaZulu-Natal (Hans, 2011) states that politics should be kept out of schools as ANC nomination for candidates in the local government elections had spilled over into violence at a secondary school in KwaZulu-Natal and teaching at this school had been halted for ten days. Political violence in South Africa often leads to high levels of intolerance and subsequently too much violence within the education system (Ngqela \& Lewis, 2012). Long debates can be held on 
the influence, and most probably more bad than good, that politics and politicians have on school performance (Farouk, 2011). Jansen (1999) states that too many incompetent stakeholders in key positions have been appointed for political reasons. The influence of politics can be seen in various spheres of education. The Grade 12 results are skewed during the standardization process at Umalusi to create an illusion of educational growth and prosperity (Tlhabi, 2011; Yeld, 2010). Furthermore, the ANC Youth League tackles issues on nationalization and land reform, but education issues are neglected (Landsdowne, 2011). With the changing of the curriculum once more in 2011, MECs of education in the nine provinces are under pressure to show that they can do something constructive and transformative during their term of office (Bertram, 2011). The South African Democratic Teachers' Union (SADTU) with the overall majority of 240000 teachers as members has a key role to play towards achieving transformation, but the Union has had a highly detrimental effect on education in the country. The inherent threat is for the union to conflate its educational leadership role with its political one (Lee, 2011). Furthermore, the Limpopo textbook crisis where textbooks were not delivered on time for the new school year in 2012 calls into question the claim by the government that the provision of quality education is one of their key five priorities and it is felt that action should have been taken against those responsible for this crisis. Instead, politicians at various levels of government are blaming each other, with no one being held accountable for the non-delivery of textbooks. It has become a truism that the Minister of Basic Education, Motshekga, is, in a manner of speaking, guilty of sleeping at the wheel there have been urgent and repeated calls for President Zuma to fire her (Anon, 2012a). Zuma himself has not escaped blame for the intensity of the education crisis (Lekota, 2012). It is also not a surprise that local government has persistently been vulnerable to exploitation and corruption which includes nepotism, the fraudulent awarding of tenders, and the circumvention of procurement processes (Oppelt, 2012). This leads to distrust and is demotivating as even the ANC educationalist and architect of OBE, Graeme Bloch (Du Plessis, 2009) admitted that the implementation of OBE had been a mistake.

Unions also add to further instability regarding education. In 2010, SADTU threatened a total shutdown of all public services, including essential services, if the government did not yield to its wage demand (Mbanjawa, 2010). The Democratic Alliance (DA) leader, Helen Zille, accused SADTU of denying pupils in the Eastern Cape, and the rest of the country, the basic right to education. She strongly stated that SADTU and COSATU (Congress of South African Trade Unions) were destroying children's future as strikes at the beginning of 2012 to protest against redeployment of teachers denied learners' right to education (Wilson, 2012). In this process unions were being used as a launching pad for political careers (as suggested earlier), rather than to resolve disputes of workers (Wilson, 2012). The Eastern Cape Education Department has threatened to take drastic action against members of SADTU who brought the administration of education to a virtual halt across the province during the first quarter in 2012 (Zandile, 2012). SADTU members invaded district education offices ordering staff to abandon their duties until the department had committed to reinstating temporary teachers whose contracts had been terminated (Zandile, 2012). SADTU also demanded that subject advisors should not visit classes (Du Plessis, 2010). Another SADTU teacher ploughed her car into children she teaches, and admitted that she wanted to kill a DA member. Education as a social responsibility of the state charges teachers with an in loco parentis responsibility and entails an affinity between children and their teachers (Komsana, 2012). Quite ironically, President Zuma gave SADTU a benediction when he extended his appreciation to this union in his state of the nation address (Komsana, 2012).

\subsubsection{Corruption}

Many changes have been made to the curriculum and have had to be implemented from 2011 to 2012 . The Minister of Basic Education is blamed for an inability to procure the basics of education on time and then not being able to provide education (Greenshields, 2012). This action necessitated the printing and delivering of textbooks to schools in January 2012 (Mpofu, 2012; Jika, 2012). In the midst of the Limpopo textbook debacle, it seems as if corruption should be considered as being responsible for this disaster (Jika, 2012). A company, EduSolutions, received alleged illegitimate contracts to deliver educational toys for Grade R for the possible amount of R27 million (Jika, 2012; Anon, 2012b). The textbook tender would have reached R700 million over a period of two years but was cancelled (Jika, 2012). Despite this fiasco it seems as if the option of firing the Education Minister is not a real one (Mpofu, 2012). In this regard a task team will be established to investigate the challenges that led to the textbook incident in the Limpopo Province (Mpofu, 2012; Jika, 2012). 
The outflow on non-delivery of textbooks in the Limpopo province meant that $70 \%$ of Grade 10 s across 25 schools failed their June 2012 exams. This amounts to 3174 of 4529 learners with principals confessing that this might be the case across the province (Govender \& Shoba, 2012). Evidence is clear that the failure to deliver books on time is solely the responsibility of the Limpopo Education Department although they are blaming contractors for not delivering the books or delivering incorrect books to schools (Louw-Carstens \& Van den Berg, 2012). In this regard, 1371 schools were affected and repeated promises were made by the Minister of Basic Education, Min. Motshekga, that books would be delivered on time (Govender, 2012b).

\subsubsection{Socio-economic factors}

It was estimated in 1995 that about $28 \%$ of households and $48 \%$ of the population were living below the estimated poverty line (Steyn et al., 2011). More than 12 million children live in households with a per capita income of less than R350 and it is indicated that the quality of teaching, learning and educational performance shows overall poor learner performance and considerable variation between provinces, districts and schools when linked to material resources, social class and type of residence (Spreen \& Vally, 2010). Also, the pervasive condition of poverty is linked to unemployment, resulting in economic survival through selling alcohol and drugs as the temptation is always there for learners in poverty-stricken areas to give in to gangsters who are offering protection money (Benjamin, 2011a). This behaviour leads to the use of weapons and joining gangs and this violent behaviour spills over to schools (Ngqela \& Lewis, 2012).

In the light of the challenges discussed above it is now deemed necessary to propose recommendations for the education system in South Africa.

\section{RECOMMENDATIONS FOR EDUCATION IN SOUTH AFRICA}

In this regard cognisance should be taken of the International Education Conference in 2011 in the USA. During this conference it became clear that Finland and Singapore stood out for excellence in education (Alston, 2011). The question asked by the researchers is why these countries excel. One of the reasons posed was that both these countries recognise the critical importance of a high quality of education and this is translated into high quality training and support (Alston, 2011).

When compiling recommendations for education in South Africa in order to achieve high quality education the focus should be on the following:

- $\quad$ Recommendations influencing learners, which would include dealing with violence in schools, low moral values, high dropout rates, and late coming, absenteeism and truancy.

- $\quad$ Recommendations influencing teachers which include aspects such as the impact of OBE and C2005, poor results in literacy and numeracy, under-performance by educators and lack of effective school governance.

- Recommendations with regard to outside factors which include lack of community support, politics in South African schools, corruption and socio-economic challenges.

\subsection{Recommendations influencing learners}

Violence taints the school environment and jeopardizes the educational process (Ngqela \& Lewis, 2012). Schoeman (2010) alleges that young people who are exposed to violence are themselves more likely to get caught up in the cycle of violence, either as victims or as perpetrators. Although an international problem, the youth of South Africa have virtually normalised crime and violence as a method to acquire status or to establish control over their environment (Pelser, 2008). An adaptive coping mechanism is an unconscious shutting out of traumatic events where children are unable to remember certain traumatic events and they become cut off from their memories, their thoughts and their feelings (Benjamin, 2011b). Benjamin (2011b) also states that many children's brains function in a mode where the brain stem is activated to ensure survival and this renders a child unable to learn because their brains remain hyper-alert. Therefore, children have outbursts of aggression and rage in response to very small triggers and reveal high risk behaviours fuelled by the need for immediate gratification (Schoeman, 2010). 
Violence in schools cannot be ignored as acts of violence have become intolerable and strategies should be developed that will prevent school violence (Ngqela \& Lewis, 2012). If causes and effects of violence on learners could be understood, it would assist in developing interventions that would help those affected by violence (Schoeman, 2010). This is essential as nearly one-third (31.4\%) of South Africa's population is under the age of 15 years (Statistics South Africa, 2009). Schoeman (2010) states that in these phases of development young people are still in a process of social, emotional and cognitive development and the potential exists to change existing antisocial behaviour.

Weaver (2011) states that paramount to success in this new world are mutual respect, understanding, flexibility, adaptability, creativity, spontaneity and the ability to learn. In order to create some kind of stability and to take account of the rapidity of change, it is important that the discipline instilled in children in schools is driven by inner principles and values, rather than by controlling rules imposed from the outside. The role of schools needs to change within this context. Children need to be encouraged to develop an inner discipline created by understanding and respecting the underlying principles and values that underpin rules (Weaver, 2011).

The importance of positive reinforcement and recognition in children's development cannot be overemphasized and teachers should strive to exercise this far more often than discipline.

When keeping the above in mind it is also necessary to suggest the following:

- $\quad$ Security measures at schools need to be intensified to promote an effective environment of learning and teaching (Ngqela \& Lewis, 2012).

- $\quad$ Programmes to eliminate violence should be introduced as such programmes will not only prevent violence but can also be used to break behavioural patterns associated with violent behaviour. It can be argued that what is learned can be unlearned and new ways of behaving can be adopted (Schoeman, 2010).

- It is also important that trauma and counselling support should be available to learners in violence-stricken areas and should include debriefing in crisis situations and in-depth therapy where necessary (Grant in Fredericks, 2011a).

- It is also critical to understand that discipline is the responsibility of teachers in partnership with parents who need to agree on what is appropriate so that they can support each other in cultivating the kind of values that society needs (Weaver, 2011).

- It is also important to upgrade standards of education in all the grades. The fact that learners do not pass Grades $1-7$, but automatically progress with age leads to a bottleneck situation in Grades $10-11$, where learners are retained and can no longer pass based on age, in order to pass only the non-risk learners to Grade 12 which will result in a better national, and therefore skewed, pass rate (Rademeyer, 2012).

\subsection{Recommendations influencing teachers}

The country cannot continue to have schools that produce poor results year after year with no visible intervention from principals and teachers. Children can no longer be victims of unqualified or under-qualified teachers (Alston, 2011).

It is noted that management is the biggest let-down and performance agreements between principals and the Department of Education are vital to uproot the laid-back culture at some schools in the province (Editorial comment, 2011). A proposal from the Department of Basic Education suggests that principals should be demoted or fired for poor results and if they fail to monitor teacher performance or managing absenteeism levels (Govender, 2011). Teachers are also blamed for absenteeism and staying away from school for weeks while earning their full salary (Moloto, 2012).

Equally important is that the teaching profession is one that people take pride in (Alston, 2011). In this regard recommendations need not always be big-bang changes. Initially the changes must be small across a wide range of areas. It will especially require changing a deeply ingrained culture of inefficiency in producing learner achievement (HSRC, 2012). Ngqela and Lewis (2012) also indicate that educators show a lack of adequate classroom management skills. It should be realised that effective teaching and learning can only take place in a safe 
and secure environment (Ngqela \& Lewis, 2012). A genuine partnership with parents requires a substantial change in teacher attitudes and practices (Mestry \& Grobler, 2007, Naong \& Morolong, 2011).

As the above remains complex, recommendations cannot be seen as the figurative "one-size-fits-all" approach. Therefore, recommendations are categorized for education departments, tertiary institutions, for schools, and for teachers:

- With regard to education departments, training initiatives must be revised and must be ongoing. The Department of Basic Education should ensure that teaching and learning support materials, as well as departmental curriculum documentation, reach schools in time. Schools should be provided with examples of learning programmes, work schedules, lesson plans and assessment instruments such as rubrics, matrices, checklists observation sheets, test and examination papers and memoranda (Meyer \& Warnich, 2010).

- $\quad$ Schools must develop school-based assessment policies, give continuing guidance and support to teachers and educate parents about OBE and assessment practices (Meyer \& Warnich, 2010).

- $\quad$ Teachers should accept the challenge of being the primary facilitators of learner success and ensure that all teaching, learning and assessment activities are meaningful and focused on the desired outcomes. They should also have a clear understanding of the purposes of assessment and should not assess for the sake of assessment or for purposes of window-dressing. This will include timely, meaningful and constructive feedback to learners and parents (Meyer \& Warnich, 2010).

- High quality training which is less theoretical and more focussed on practical implementation must be provided. It should also be more frequent and ongoing based on the model of Continuous Professional Development (CPD) that is followed in other professions. By accumulating CPD points, the teacher could be rewarded by means of bonuses or other incentives (Meyer \& Warnich, 2010). Teacher-training programmes should also address the impact of parent involvement in schools (Naong \& Morolong, 2011).

- Thoroughly trained and experienced subject advisors should visit schools on a regular basis to monitor the implementation of OBE (Meyer \& Warnich, 2010).

- $\quad$ Schools should be provided with the necessary physical infrastructure, facilities and equipment so that effective teaching, learning and assessment can take place (Meyer \& Warnich, 2010).

- Reclassification of functions into categories of expertise should address the challenges and that full-time posts for specialised functions, such as financial management and resource management should be created at either school - or district levels (Xaba, 2011). Xaba (2011) also recommends that a dedicated governance unit at district level should be established to render continuous and consistent support to governing bodies in the district.

- $\quad$ Performance agreements will ensure that schools are measured on results and that principals will focus on what teachers are doing in the classroom in order to improve performance (Editorial comment, 2011).

- $\quad$ The Department of Basic Education should invite senior personnel from Finland and Singapore and allow our educationists to listen to how others are getting it right (Alston, 2011).

- Tertiary institutions should liaise closely with education departments with regard to teacher training programmes and the curricula. They should also continuously focus their research on OBE related issues and share their findings and recommendations with departments of education, schools, teachers and unions (Meyer \& Warnich, 2010).

\subsection{Recommendations focusing on outside factors}

It is of the utmost importance that government should take responsibility of their actions. In this regard the following recommendations are made:

- $\quad$ Politicians should learn from mistakes made and appoint skilful and qualified people and not the so-called cadres who are thrusting the country into poverty and enriching themselves without contributing to the economy of the country (Jansen, 1999).

- $\quad$ Apartheid excuses should be limited. The Auditor-General, Terence Nombembe, released his 2010-2011 local government report that made a mockery of Zuma's apartheid excuses (Oppelt, 2012). Ironically, this 
report is a damning indictment, not of the past, but very much of the present ANC government that has been in power for 18 years (Oppelt, 2012; Mokoena, 2011). Although the legacy of apartheid is admitted and it is recognised that the consequences will take time to overcome (Staff Reporter, 2011), it tends to be the sjambok used by President Zuma to blame apartheid and Verwoerd (Oppelt, 2012, Tlhabi, 2012) for ongoing disastrous decision-making. The reality is that there is no political will to enforce the law or to meet public expectations of probability, efficiency and delivery (Anon, 2012b; Anon, 2012c). Badat (in Pather, 2011) states that although the effects of apartheid had been pervasive it cannot forever be hold culpable. One cannot help but agree with Tlhabi (2012) that denying children their education is not what the people signed for in 1994.

- Schools need to be designed in such a way to educate substantial numbers of youth out of poverty (Thomas, 2012). Although many mainstream schools are located in historically disadvantaged communities, research by Grant et al. (2010) indicate that schools that succeeded had a sense of pride in the neatness and tidiness of the school, good attendance and punctuality on the part of the educators and the learners and efficient use by education of time and the meagre resources at their disposal. These fundamentals also include the importance of an educational vision to guide the school as it moves forward while at the same time ensuring that systems, structures and procedures are in place to hold the school steady and maintain their functioning on a daily basis. Low quality education is entrenching academic exclusion for many despite the government's redistributive thrust and increased expenditure (Motala in Gernetzky, 2011b). Lewin (in Gernetzky, 2011b) warns that when taking the high enrolment figure into account, the country is facing a problem of "silent exclusion" where learners attend school but do not learn anything and eventually fail to complete secondary education. Thus, school teaching must become a profession of preference and pride. The picture is bleak, but there are also pockets of excellence where schools thrive and excel. This is even the case in some instances of historically disadvantaged schools where poverty, gangs and drug abuse surround specific areas (Johns, 2011).

- With regard to the unions it is important that the government deal with COSATU's and SADTU's obstructionist policies. Cadre deployment should be scrapped (Kaye, 2011).

- The Labour Relation Act 1995 (LRA, 1995) states that no person may take part in a strike if that person is engaged in an essential or maintenance service but does not specify which services can be classified as essential and it is felt that education should be made an essential service where officials will not be allowed to strike (Gernetzky, 2012; Mle, 2012; Alston, 2010). This suggestion is welcomed by some ANC members but strongly opposed by SADTU (Gernetzky, 2012). It is indeed time to limit the freedom to strike and to call for limits to unionisation (Mle, 2012).

- In September 2012 the Cabinet, in the context of the National Development Plan, adopted a strategic framework to form the basis of future detailed planning. This initiative should function as a watchdog where newly-qualified teachers would need to demonstrate certain competencies before they are employed in schools and after that they would be offered preliminary certification to be finalised based on demonstrated competence (Anon, 2012d). This certification needs to be renewed periodically. This initiative implies changes to the way school principals are appointed, including to move to eliminate union influence in promoting or appointing principals (Anon, 2012d).

\section{CONCLUSION}

The dismal position of education in South Africa has been outlined and assessed. The researchers need to mention that there are pockets of excellence, but unfortunately these are in the minority and are sustained by capable individuals and not by the system itself. The challenges facing the schooling system are immense and it is necessary that the recommendations be implemented by all stakeholders. Ironically, it is not major changes and high cost input that will ensure a success rate in education in South Africa, but rather the intangibles that have to do with a good social fabric. Most importantly, moral values within individuals, families, schools and communities should be realised and instilled. Teachers should also take pride in their professions and realise that teaching should return to basic concepts such as teaching reading writing and arithmetic. If these foundations form the roots of education then only the proposed recommendations will have a major impact on education in South Africa where all citizens will benefit. 


\section{AUTHORS INFORMATION}

Dr. N. Mouton, Manager: Admissions and Records, North-West University, Private Bag X2046, Mmabatho, South Africa, 2735. E-mail: 10516387@nwu.ac.za (Corresponding author)

Prof. G.P. Louw, School of Post-Graduate Studies, North-West University, Private Bag X 2046, Mmabatho, South Africa 2735. E-mail: 10056394@nwu.ac.za

Prof. G.L. Strydom, School of Biokinetics, Recreation and Sports Science, North-West University, Private Bag X6001, Potchefstroom, South Africa, 2520. E-mail: 10172521@nwu.ac.za

\section{REFERENCES}

1. Alston, K. (2010, July 21). Education must be an essential service for the good of SA. Daily Dispatch, p 4.

2. Alston, K. (2011, April 12). School teaching must become profession of preference, pride. Daily Dispatch, p 7.

3. Anon. (2012a, July 22). Textbook crisis demands action and imagination. Sunday Times, p 4.

4. $\quad$ Anon. (2012b, June 25). Regering het nie nog mag nodig nie. Beeld, $\mathrm{p} 10$.

5. $\quad$ Anon. (2012c, July 29). Put a price on inaction. Sunday Times, $\mathrm{p} 4$.

6. $\quad$ Anon (2012d, September, 9). A road map to take SA where it needs to go. Sunday Times, p 4.

7. Benjamin, L. (2011a, September 19). Living in a state of emergency - a generation ruled by fear and frustration. Cape Times, $\mathrm{p} 11$.

8. Benjamin, L. (2011b, September 19). Where kids go to school as bullets fly. Cape Times, p 11.

9. $\quad$ Bertram, C. (2011, June 9). Rushing curriculum reform again. Mail and Guardian, p 39.

10. Bezuidenhout, N. (2011, September 23). School tense as deadly gang fights intensify. Cape Argus, p 3.

11. Christie, P \& Potterson, M. (1997). School Development in South Africa: A research project to investigate strategic interventions for Quality improvement in South African schools. Johannesburg: University of Witwatersrand.

12. Citizen Reporter. (2011, January 27). MEC orders intervention at school with 57 teen pregnancies. The Citizen, $\mathrm{p} 6$.

13. Department of Education (DoE). (1996). South African Schools Act No. 84 of 1996. Pretoria: Government Gazette.

14. Department of Education (DoE). (1997). Curriculum 2005 - Lifelong learning for the $21^{\text {st }}$ century. Pretoria: Absolutely Media Marketing.

15. Du Plessis, T. (2009, October 2). Als was toe nie so sleg. Beeld, p 12.

16. Du Plessis, A (2010, September, 18). Gaan soek fout in onderwys hier. Burger, p 7.

17. Editorial Comment. (2011, January 19). Make school principals accountable for results. The Herald (EP Herald), p 16.

18. Farouk, J. (2011, April 5). Preference for politics is harming our school. Star, p 7.

19. Fiske, E. \& Ladd, H. (2004). Balancing public and private resources for basic education: school fees in post-apartheid South Africa. In Chisholm, L., ed. Changing Class: Education and social change in postapartheid South Africa. Cape Town: Compress. p 55-88.

20. Fredericks, I. (2011a, November 3). Children dodge bullets on the way to school. Cape Argus, p 8.

21. Fredericks, I. (2011b, April 18). 32\% of coloured teens aged 16 and older not at school. Cape Argus, p 6.

22. Fredericks, I. (2011c, June 2). Pupils must be in school when not writing exams. Cape Argus, p 4.

23. Gernetzky, K. (2011a, June 29). Shock study on school literacy, numeracy. Business Day, p 1.

24. Gernetzky, K. (2011b, July 27). School enrolment in SA high, but pupils "may not learn anything". Business Day, p 4.

25. Gernetzky, K. (2012, July 3). Policy conference has climbed down on education. Business Day, p 3.

26. Govender, P. (2011, July 24). "We don't want to teach little kids". Sunday Times, p 10.

27. Govender, P. (2012a, September 4). Expulsion on the cards for school heads who fail. Sunday Times, p 9.

28. Govender, P. (2012b, July 8). New textbook shock for Limpopo. Sunday Times, p 1.

29. Govender, P. \& Shoba, S. (2012, July 22). Textbook fiasco shows in mid-year results. Sunday Times, p 1. 
30. Grant, C., Jasson, A. \& Lawrence, G. (2010). Resilient KwaZulu-Natal schools: an ethics of care. Southern African Review of Education, 16(2), 81-99.

31. Greenshields, D. (2012, July 5). The state and its assets belong to all. The Star, p 24.

32. Halata, C. (2011, November, 2). Gangsters enter school to attack learner. Diamonds fields advertiser, p 5.

33. Hans, B. (2011, February, 18). Politics closes school. Witness, p 1.

34. Harley, K. \& Wedekind, V. (2004). Political change, curriculum change and social formation, 1990 to 2002. In L. Chisholm (Ed.). Changing Class: Education and social change in post-apartheid South Africa. Cape Town: Compress. p 195-220.

35. Herbst, J \& Mills, G. (2012, July 29). Challenges on the road to prosperity for Africa. Sunday Times, p 4.

36. Howie, S. (2004). A national assessment in mathematics within an international comparative assessment. Perspectives in education, 22(2), 149-161.

37. HSRC. (2012). The low-achievement trap: Changing the culture of inefficiency in teaching. Review, 10(2), 16-18.

38. Jansen, J.D. (1999). Why outcomes-based education will fail: an elaboration. In Education in South Africa. Cape Town: Juta. p 145-156.

39. Jika, T. (2012, June 30). Limpopo: Dis handboeke en speelgoed. Beeld, p 9.

40. Johns, L. (2011, August 31). School comeback builds community spirit. Cape Argus, p 16.

41. Jones, M. (2011a, June 20). High school dropout rate shock. Daily News, p 5.

42. Jones, M. (2011b, April 27). Bold new school fees plan. Times, p 1.

43. Kaye, S. (2011, June 13). Development state requires a solid foundation. Star, p 14.

44. Komsana, K. (2012, April 18). Reckless act reflects culture of impunity. Daily Dispatch, p 11.

45. Kruger, C. (2012, September 2). $20 \%$ van leerlinge in gr 10, 11 is herhalers. Rapport, p. 8.

46. LRA see Labour Relations Act.

47. Labour Relations Act (LRA). 1995. (Act 66 of 1995). Government Printers: Pretoria.

48. Landsdowne, A. (2011, July 4). ANC has lost the plot on priorities for SA youth. Cape Argus, p 12.

49. Lee, N. (2011, January 6). High time for Sadtu to do some soul-searching. Star, p 10.

50. Lekota, M. (2012, July 5). Zuma's race talk amounts to a failure to uphold constitution. The Star, p 24.

51. Lombard, B.J.J. (2010). Outcomes-based education in South Africa: a brief overview In Meyer, L, Lombard, K, Warnich, P \& Wolhuter, C. Outcomes-based assessment for South African Teachers, Van Schaik's Publishers: Pretoria. p. 1-29.

52. Louw-Carstens, M \& Van den Berg, M. (2012, June 29). Skole se boeke: Hoofde kry nou die skuld. Beeld, p 4.

53. Matoti, S.N. (2010). The unheard voices of educators: perceptions of educators about the state of education in South Africa. South African Journal of Higher Education, 24(4), 568-584.

54. Matshidisa, M.N. (2007). Educators' perceptions of outcomes-based education (OBE) assessment. Potchefstroom: North-West University. (Dissertation-MeD).

55. Mbanjawa, M. (2010, August 19). It's “war" on public services: SADTU. Daily News. p 1.

56. Mestry, R. (2004). Financial accountability: The principal or the school governing body? South African Journal of Education, 26, 27-38.

57. Mestry, R. \& Grobler, B. (2007). Collaboration and communication as effective strategies for parent involvement in public schools. Educational Research and Review, 2(7), 176-185.

58. Meyer, L.W. \& Warnich, P.G. (2010). Outcomes-based education and outcomes-based assessment in South African schools: the way forward? In Meyer, L, Lombard, K, Warnich, P \& Wolhuter, C. Outcomes-based assessment for South African Teachers, Van Schaik's Publishers: Pretoria. p. 161-173.

59. Mle, T.R. (2012). A critical analysis of the 2010 public service strike in South Africa: a service delivery approach. Journal of Public Administration, 1(47) March, 291-298.

60. Mokoena, M. (2011, August 12). Minister blames apartheid for poor school performance. Diamond fields advertiser, $\mathrm{p} 10$.

61. Moloto, M. (2012, August 1). Comrades hero's coach bunked school. Star, p 5.

62. Mpofu, M. (2012, July 5). Motshekga's job is still safe. The Star, p 6.

63. Naong, M \& Morolong, I. (2011). Challenges to parental involvement in school governance. Acta Academica, 23(2), 236-263.

64. Nel, C. \& Kistner, L. (2009). The National Senior Certificate: Implications for access to higher education. South African Journal for Higher Education, 23(5), 953-973. 
65. Ngqela, N. \& Lewis, A. (2012). Exploring adolescent learners' experiences of school violence in a township high school. Child Abuse Research: A South African Journal, 13(1), 87-97.

66. Nkosi, B. (2012, August 17). Teachers unprepared for new curriculum. Mail \& Guardian, p 14.

67. Oppelt, P. (2012, July 29). Apartheid is to blame. Sunday Times, p 5.

68. Pather, D. (2011, January 23). How to stop the rot in our school system. Sunday Tribune, p 14.

69. Pelser, E. (2008). Learning to be lost: youth crime in South Africa. Discussion Paper for the HSRC Youth Policy initiative, Reserve Bank, Pretoria. 13 May.

70. $\quad$ Potgieter, M. (2010, February 19). Skoksyfers oor gr. 6 leerders. Burger, p 1.

71. Potgieter, A. \& Davidowitz, B. (2010). Gr 12 achievement rating scales in the new National Senior Certificate as indication of preparedness for tertiary chemistry. South African Journal of Chemistry, (6)63, 75-82.

72. $\quad$ Rademeyer, A. (2012, August 31). 1 m. herhaal hul skooljaar. Beeld, p 16.

73. Reyneke, E.M. (2008). A model for outcomes-based assessment of English first additional language in the further education and training band. Potchefstroom: NWU. (Thesis $-\mathrm{PhD}$ ).

74. Rogan, J.M. (2000). Strawberries, cream and the implementation of curriculum 2005: towards a research agenda. South African Journal of Education, 20(2), 118-125, May.

75. Schoeman, M. (2010). Prevention of youth violence - what is learned can be unlearned. Child Abuse Research: A South African Journal, 11 (2), 9-20.

76. Sifile, L. (2011, June 23). 7-year old tells of rape at school. Daily Dispatch, p 5.

77. Spreen, C.A. \& Vally, S. (2010). Outcomes-based education and its (dis)contents: Learner-centred pedagogy and the education crisis in South Africa. Southern African Review of Education with Education with Production, 16(1), 39-58.

78. Staff Reporter. (2011, May 28). Call for kids to get to school on time. Saturday Star, p 4.

79. Statistics South Africa. (2009). Mid-year population estimates. Available at: http://www.statssa.gov.za/publication/P03022009.pdf.

80. Steyn,H.J., Steyn, S.C.\& De Waal, E.A.S. (2011). South African Education System, Keurkopie: Potchefstroom.

81. Tau, M. (2011, June 2). Pupils skip school due to on-going violence. The Citizen, $\mathrm{p} 3$.

82. Tlhabi, R. (2011, Feb 25). Public's trust in Umalusi wiped out. Sowetan, p 19.

83. Tlhabi, R. (2012, July 29). Verwoerd's work goes on, only now it's the ANC crushing black children. Sunday Times, $\mathrm{p} 2$.

84. Thomas, M. (2012, August 17). Success can be a matter of principal. Mail \& Guardian, p 38.

85. Waghid, Y. (2001). Is outcomes-based education a sufficient justification for education? South African Journal of Education, May 21(2), 127-132.

86. Warnich, P.G. (2008). Uitkomsgebaseerder assessering van Geskiedenis in Graad 10. Potchefstroom: North-West University. (Thesis - PhD).

87. Warnich, P.G. \& Wolhuter, C.C. (2010). Outcomes-based assessment in South Africa: issues and challenges. In Meyer, L., Lombard, K., Warnich, P. \& Wolhuter, C. Outcomes-based assessment for South African Teachers, Van Schaik's Publishers: Pretoria. p. 63-82.

88. Weaver, S. (2011, August 15). What should school discipline look like today? Witness, p 15.

89. Wilson, G. (2012, March 22). Zille leads PE protest. The Herald, p 1.

90. Xaba, M.I. (2011). The possible cause of school governance challenges in South Africa. South African Journal of Education, 31, 201-211.

91. Yeld, D. N. (2010, February 28). Unadjusted pass rates for matric subjects tell true story of state of education. Cape Times, p 9.

92. Zandile, M.N. (2012, February 7). Education shutdown. The Herald, p 1.

93. Zewotir, T. \& North, D. (2011). Opportunities and challenges for statistics education in South Africa. Pythagoras, 32 (2), Art 28. http//dx.doi./org/10.4102/pythagoras.v32/2.28 